\title{
Autecology of Drosera burmanni in the Wolobobo Botanic Gardens, Ngada District, Flores Island, Indonesia
}

\author{
JOKO RIDHO WITONO ${ }^{1, \bullet}$, DIDI USMADI ${ }^{1}$, WIHERMANTO ${ }^{1}$, DANANG WAHYU PURNOMO ${ }^{1}$, \\ DINA SAFARINANUGRAHA ${ }^{1}$, YANUAR PAKIDING ${ }^{2}$, NELWAN NETOSESO ${ }^{2}$ \\ ${ }^{1}$ Research Center for Plant Conservation and Botanic Gardens, Indonesian Institute of Sciences. J1. Ir. H. Juanda 13, Bogor 16122, West Java, Indonesia. \\ Tel./fax.: +62-251-8322187, `email: jrwitono@yahoo.com \\ ${ }^{2}$ Planning, Research and Development Agency, Ngada District. Jl. Gajah Mada, Bajawa, Ngada District 86415, East Nusa Tenggara, Indonesia
}

Manuscript received: 24 March 2020. Revision accepted: 22 April 2020.

\begin{abstract}
Witono JR, Usmadi D, Wihermanto, Purnomo DW, Safarinanugraha D, Pakiding Y, Netoseso N. 2020. Autecology of Drosera burmanni in the Wolobobo Botanic Gardens, Ngada District, Flores Island, Indonesia. Biodiversitas 21: 2137-2145. Drosera burmanni Vahl is a native carnivorous plant from tropical and subtropical Asia to the West Pacific, including Flores Island. During the botanical survey, a small population of the species was found in a limited area in the Wolobobo Botanic Gardens, Flores Island. Conservation of the species is necessary, since the habitat might be developed for the botanic gardens infrastructure. This research aims to study the autecology of D. burmanni, including environmental preferences and its associated species. Thirty plots with $2 \times 2 \mathrm{~m}$ each were made to recognize its associated species and the pattern of its population distribution and its soil requirements. In the Wolobobo Botanic Gardens, D. burmanni flourishes with an average annual rainfall of $1835 \mathrm{~mm}$; a temperature of $12.5^{0}-26.2^{\circ} \mathrm{C}$; $48-99 \%$ humidity; at an altitude of 1489-1491 m asl.; a soil $\mathrm{pH}$ of 6.66 , which contains very high C-organic, a high $\mathrm{C} / \mathrm{N}$ ratio, moderate $\mathrm{N}$ total, $\mathrm{K}_{2} \mathrm{O}, \mathrm{P}_{2} \mathrm{O}_{5}, 10 w$ $\mathrm{CEC}$, and very low $\mathrm{K}, \mathrm{Na}, \mathrm{Ca}, \mathrm{Mg}$, and BS. Drosera burmanni displays a density of 8.5 individuals per $\mathrm{m}^{2}$ and is associated with 20 species, which belong to 19 genera and 9 families. The species has a clustering pattern and a positive association with Erigeron sumatrensis, Spinifex littoreus, and Imperata cylindrica. To conserve D. burmanni in the Wolobobo Botanic Gardens, it is necessary to designate its natural habitat as an in situ conservation area.
\end{abstract}

Keywords: Associated species, carnivorous plant, climatic and soil requirements, distribution pattern, in situ conservation

\section{INTRODUCTION}

Drosera L. belongs to the family Droseraceae Salisb. (APG IV 2016) and is a genus of cosmopolitan herbaceous carnivorous plants with the highest number of species compared with other genera of carnivorous plants. According to Robinson et al. (2017) and Fleischmann et al. (2018), Drosera is estimated to consist of ca. 250 species with the highest diversity in Australia (ca. 110 species). At present, the genus consists of 247 accepted species (http://www.plantsoftheworldonline.org 2020). Most Drosera species are annual hemicryptophytic with cyme or raceme inflorescences. Drosera species are usually tolerant of suboptimal environmental conditions and adapt to various habitats for their reproduction and survival (Ellison and Gotelli 2009).

Drosera in Indonesia consists of seven species: $D$. banksii R.Br. ex DC., D. rotundifolia L., D. burmanni Vahl, D. indica L., D. petiolaris R.Br. ex DC., D. spatulata Labill., and D. ultramafica A.Fleischm., A.S.Rob. \& S.McPherson. Drosera burmanni Vahl. (the species epithet is usually orthographically corrected to burmannii) has a wide distribution and is found in the Lesser Sunda Islands (Kalkman 1955). This species grows from tropical and subtropical Asia to the West Pacific, including Australia, Indonesia, Sri Lanka, India, Bangladesh, Bhutan, Cambodia, Myanmar, Vietnam, Philippines, China, Japan, and Taiwan. In its natural habitat, this species grows in dry areas and meadow grasses from lowlands to the mountains at an altitude of $1500 \mathrm{~m}$ asl. (Zhuang 2011; http://www.theplantlist.org 2020). On Natuna Island, $D$. burmanni grows in kerangas forests and in calcareous soils on coastal areas up to $50 \mathrm{~m}$ asl. in full sun, open habitats (Mansur 2012).

The IUCN Redlist categorizes D. burmanni as Least Concern (LC) (Zhuang 2011), because this species has a wide distribution and is adaptable to various environmental conditions. D. burmanni, known as tropical sundew or serenta bumi, has been widely used as a dysentery (Mitra and Mukherjee 2010), anticonvulsant (Hema et al. 2009), antifertility (Madhavan et al. 2009), antitumor (Raju et al. 2012), and antioxidant drug (Raju and Christina 2013; Ghate et al. 2015).

Autecological research is done only at the population level (there are investigated different populations and metapopulations of one species, and only after that the data are cumulated in order to characterize autecologically a species) (Godeanu and Donita 2016). In ecology, autecology is mainly applied for conservation, such as Cyrtostacys renda Blume (Widyatmoko 2001), and Caryota mitis Lour. (Quek et al. 2020); and cultivation useful plant species, such as Reseda lutea L. (Dogan 2001), broadleaved tree species (Gonin et al. 2013), and Baccaurea angulata Merr. (Gunawan et al. 2018), Research relating to the study of the autecology and conservation of $D$. burmanni is still very limited. Several 
studies related to the association of D. burmanni with other plant species were done in India, such as Majumdar et al. (2011) and Chakraborty and Bhattacharya (2013) Similar research in Indonesia has never been reported. Based on the field survey conducted during the Wolobobo Botanic Gardens masterplan development project in Ngada District, East Nusa Tenggara, D. burmanni is only found at one location on the ridge area.

Studies relating to the autecology of D. burmanni including environmental preferences mainly climate and soil, and associated plant species need to be carried out in order to conserve the native plants in the Wolobobo Botanic Gardens. Possible changes in the landscape and infrastructure during the development of the Botanic Gardens could potentially disrupt the habitat of native plants, their identification, and especially the characterization of the important growing environment of D. burmanni. This study was conducted to study the autecology of D. burmanni, including environmental factors and associated species in the Wolobobo Botanic Gardens, Ngada District, East Nusa Tenggara. The autecological research is important as basis data for managing the habitat of $D$. burmanni.

\section{MATERIALS AND METHODS}

\section{Study area}

This research was conducted in April 2019 in the area of the Wolobobo Botanic Gardens, located in the Bajawa City, Ngada District, East Nusa Tenggara, Indonesia. This botanic gardens covers an area of 91.81 ha, located at coordinates $8^{0} 49^{\prime} 56^{\prime \prime}-8^{0} 50^{\prime} 50^{\prime \prime} \mathrm{S}$ and $120^{\circ} 58^{\prime} 33^{\prime \prime}-$ $120^{\circ} 59^{\prime} 07^{\prime \prime} \mathrm{E}$, at an altitude of 1300-1592 m asl. According to the Köppen-Geiger climate classification, the Wolobobo Botanic Gardens is included in the tropical savanna climate (Aw) (Kottek et al. 2006). The Wolobobo Botanic Gardens contains five vegetation types: remnant forest vegetation, ampupu (Eucalyptus urophylla S.T. Blake) vegetation, acacia (Acacia mearnsii De Wild.) vegetation, calliandra (Calliandra calothyrsus Meisn.) vegetation, and bushessavanna (Figure 1).

\section{Procedures}

Environmental preferences of D. burmanni were observed, mainly climate and soil. Climate data including rainfall, temperature, and humidity were obtained from www.climate.org (2020). Soil condition data were obtained by collecting soil samples in the observation plots with soil depth to the tip of the D. burmanni roots $(0-3 \mathrm{~cm}$ deep). Two soil samples, as much as $1 \mathrm{~kg}$, were collected from each observation plot for laboratory analysis. The soil variables included: soil $\mathrm{pH}, \mathrm{C}$-organic, $\mathrm{N}$-total, $\mathrm{C} / \mathrm{N}$ ratio, $\mathrm{P}_{2} \mathrm{O}_{5}, \mathrm{~K}_{2} \mathrm{O}$, exchangeable cations $(\mathrm{K}, \mathrm{Na}, \mathrm{Ca}$, and $\mathrm{Mg}$ ), Cation Exchange Capacity (CEC), and Base Saturation (BS). Soil analysis was carried out at the Environmental Biotechnology Laboratory, Bogor.

Observations of the population of $D$. burmanni were conducted using a line transect method of 30 plots of $2 \times 2$ $\mathrm{m}$ along the habitat of the species (Figure 2). In each observation plot, the number of $D$. burmanni specimens and the species and number of other plants were recorded. The plant species were identified directly in the field and herbarium vouchers were made of the unknown individuals for further identification. The research data was tabulated in the form of tables for analysis.

\section{Data analysis}

The distribution pattern of D. burmanni population was analyzed using the Standardized Morisita Index (Krebs 1989). The Morisita Index is calculated by the following equation:

$$
I_{d}=n\left[\frac{\sum x^{2}-\sum x}{\left(\sum x\right)^{2}-\sum x}\right]
$$

Where: $I_{d}=$ Morisita index, $n=$ number of observation plots, and $\mathrm{x}=$ the number of individuals found in each plot.

Furthermore, the Morisita Index obtained is searched for its two critical points, namely the $\mathrm{M}_{\mathrm{u}}$ index (Uniform Index) and the $\mathrm{M}_{\mathrm{c}}$ index (Clumped Index) through the $\chi^{2}$ test to find the degree of classification. The $M_{c}$ or $M_{u}$ is calculated using the following equation:

$$
\begin{aligned}
& M_{u}=\frac{x_{0.975}^{2}-n+\sum x_{i}}{\left(\sum x_{i}^{i}\right)-1} \\
& M_{c}=\frac{x_{0.025}^{2}-n+\sum x_{i}}{\left(\sum x_{i}^{i}\right)-1}
\end{aligned}
$$

Where: $\mathrm{X}_{0.975}=$ value of the table with df (n-1) which has $97.5 \%$ area to the right of the curve, $\mathrm{X}_{0.025}=$ value of the table with df (n-1) which has $2.5 \%$ area to the right of the curve, $\Sigma \mathrm{x}_{\mathrm{i}}=$ species number in quadratic $\mathrm{i}(\mathrm{i}=1, \ldots \mathrm{n})$, $\mathrm{n}=$ quadratic number.

Standardized Morisita Index $\left(\mathrm{I}_{\mathrm{P}}\right)$ is calculated based on one of the four following equations:

$$
\begin{aligned}
& \text { If } I_{d} \geq M_{c}>1.0: \\
& I_{p}=0.5+0.5\left(\frac{I_{d}-M_{c}}{n-M_{c}}\right) \\
& \text { If } M_{c}>I_{d} \geq 0: \\
& I_{p}=0.5\left(\frac{I_{d}-1}{M_{u^{-}}-1}\right) \\
& \text { If } 1.0>I_{d}>M_{u}: \\
& I_{p}=-0.5\left(\frac{I_{d}-1}{M_{u^{-}}}\right) \\
& \text {If } 1.0>M_{u}>I_{d}: \\
& I_{p}=-0.5+0.5\left(\frac{I_{d}-M_{u}}{M_{u}}\right)
\end{aligned}
$$

Standardized Morisita Index $\left(\mathrm{I}_{\mathrm{P}}\right)$ is -1.0 to 1.0 . If $\mathrm{I}_{\mathrm{P}}=0$, the distribution pattern is random; $I_{P}<0$, the distribution pattern is uniform; and if $I_{P}>0$, the distribution pattern is clustering.

The association between D. burmanni and other plant species is based on the presence and absence of data using a 2 × 2 m contingency table for each species pair (Table 1) (Ludwig and Reynolds 1988). 

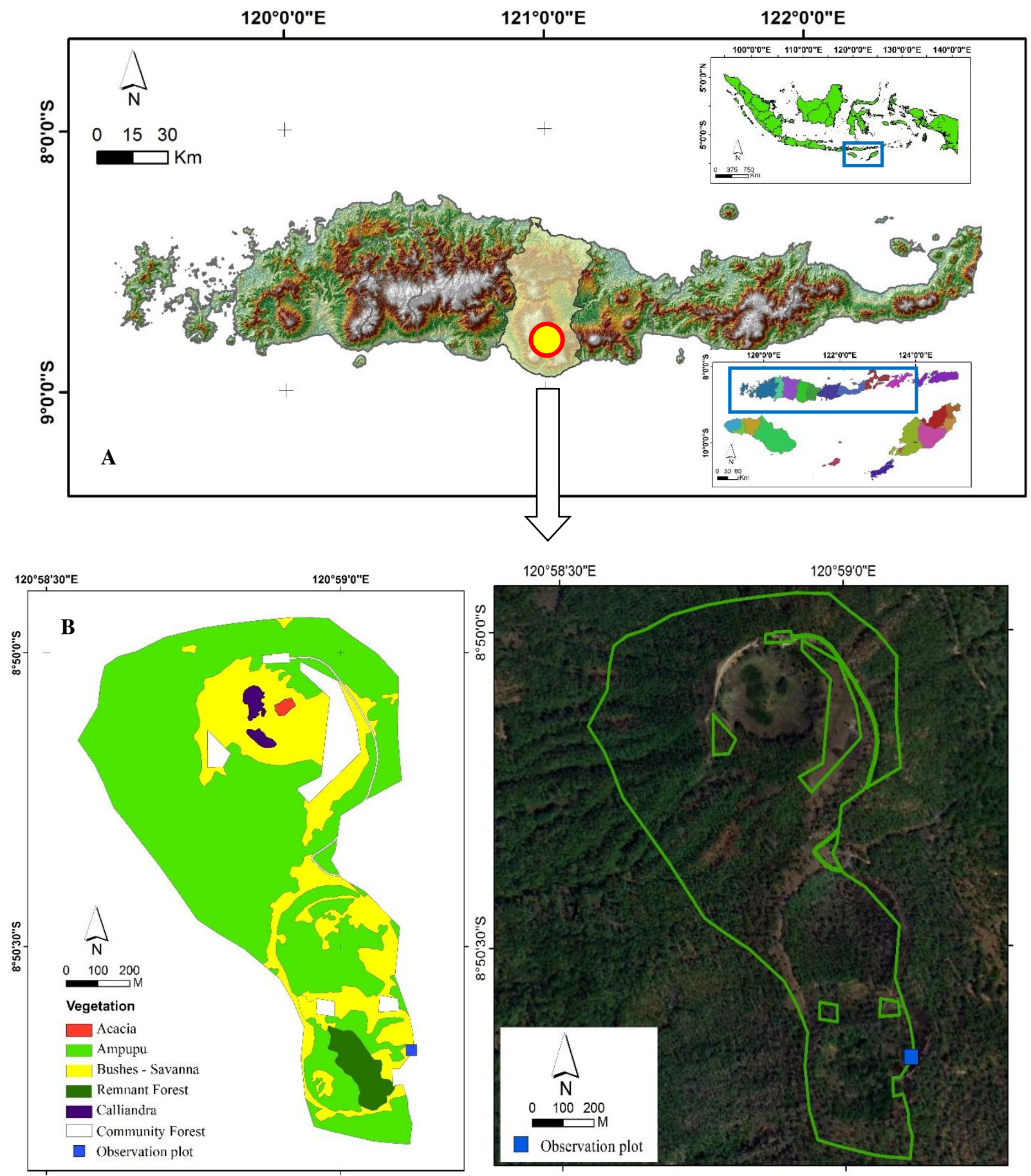

Figure 1. Research location in the Wolobobo Botanic Gardens, Ngada District, East Nusa Tenggara, Indonesia. A. Flores Island, B. Research site in the Wolobobo Botanic Gardens

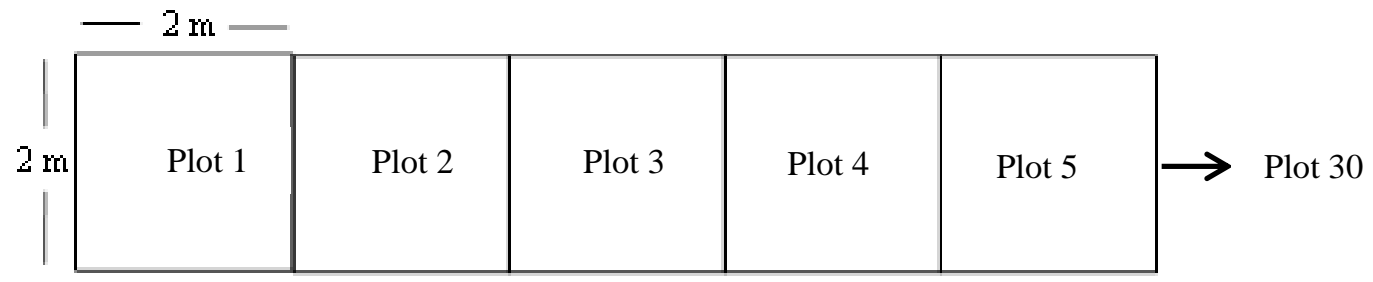

Figure 2. Observation plot 
Table 1. The 2 x $2 \mathrm{~m}$ paired contingency for species associations

\begin{tabular}{lccc}
\hline & & Species A & \\
\hline & & Present & Absent \\
& Present & $\mathrm{a}$ & $\mathrm{b} \quad \mathrm{m}=\mathrm{a}+\mathrm{b} \quad \mathrm{c}$ \\
$\mathrm{n}=\mathrm{c}+\mathrm{d} \quad \mathrm{c}=\mathrm{b}+\mathrm{d}$ & $\mathrm{c}=\mathrm{a}+\mathrm{c}$ & $\mathrm{d}+\mathrm{b}+\mathrm{c}+\mathrm{d} \quad$ \\
\hline
\end{tabular}

Note: a: the number of observation plots that contain $D$. burmanni and species A, b: the number of observation plots that contain $D$. burmanni but not species A, c: the number of observation plots that contain species A, but not D. burmanni, d: number of observation plots that do not contain either species

Determination of whether or not there is an association between $D$. burmanni and the other plant species was calculated by Chi-square value $(\chi 2)$. Chi-square values were compared with a $\chi 2$ table $(\mathrm{P}=0.05, \mathrm{df}=1)$. If the value of $\chi^{2}$ count $>\chi^{2}$ table, there is an association, but if $\chi^{2}$ count $<\chi^{2}$ table there is no association.

$$
\mathrm{X}_{\text {count }}^{2}=\frac{N(a d-b c)^{2}}{(a+b)(a+c)(b+d)(c+d)}
$$

The association character is known by comparing the observed value of a with the expected value of $E$ (a). If $a>E$ (a), the association is positive, but if a $<\mathrm{E}$ (a), the association is negative.

$$
E(a)=\frac{(a+b)(a+c)}{N}
$$

The degree of association between D. burmanni and other plant species was determined using the Jaccard similarity Index (Jaccard 1901):

$$
\text { Jaccard Index }=\frac{a}{a+b+c}
$$

\section{RESULTS AND DISCUSSION}

\section{Environmental preferences}

The Wolobobo Botanic Gardens has an average annual rainfall of $1835 \mathrm{~mm}$. The rainy season occurs from November to April and the dry season occurs from May to October. The temperature in the Wolobobo Botanic Gardens is $12.5^{\circ}-26.2^{\circ} \mathrm{C}$ with an average of $19.7^{\circ} \mathrm{C}$, and humidity of $48-99 \%$ with an average of $85 \%$ (www.climate-data.org 2020). Information relating to the climatic conditions in which D. burmanni grows on Flores, or even in Indonesia has never been reported.

Research relating to the climatic conditions in which $D$. burmanni grows is reported in 3 locations in India: (i) Tripura State, the climate of the study area is monsoonal with an average annual rainfall of $2109.3 \mathrm{~mm}$, with about $65 \%$ received during the south-west monsoon season (June to September). Cold weather conditions start at the end of November with declining temperatures. The annual mean daily maximum temperature is $25.5^{\circ} \mathrm{C}$ and the mean daily minimum is $10.4^{\circ} \mathrm{C}$ (Majumdar et al. 2011). (ii)Kas Plateau-Maharashtra state, D. burmanni grows well in locations with an annual rainfall of 3890-4570 $\mathrm{mm}$ and humidity of $60-70 \%$. The species blooms from August to October (Pawar et al. 2012). The Kas or Kaas Plateau was designated a World Heritage Site by UNESCO in 2012 (Lele 2015). (iii) Jalpaiguri-West Bengal State, $D$. burmanni grows in locations with an annual rainfall of more than $3000 \mathrm{~mm}$, maximum rainfall occurs in April to September (995-996.5 mm) with a temperature of $5.5^{0}-37^{0}$ C (Chakraborty and Bhattacharya 2013).

Based on our field observations and those of previous studies, D. burmanni grows in places with an annual rainfall of $1835-4570 \mathrm{~mm}$, a temperature of $5.5^{\circ}-37^{0} \mathrm{C}$, and a humidity of $48-99 \%$. In cultivation, the species grows optimally at a temperature of $20^{\circ}-25^{\circ} \mathrm{C}$ and adult plants are best managed in small pots in trays of water. They do very well under a constant light cycle in terrariums at normal house temperatures (Brittnacher 2020).

Drosera burmanni was found in the Wolobobo Botanic Gardens at an altitude of 1489-1491 m asl. On Natuna Island, this species is found growing in kerangas forest and calcareous soil, from the beach up to $50 \mathrm{~m}$ asl., close to water sources, and in full sun, open spaces (Mansur 2012). Habitat information of D. burmanni in other locations in Indonesia has never been reported. Previous research on the habitat of D. burmanni has been reported in India and the Malay Peninsula. According to Madhavan et al. (2009), it grows from the lowlands to the mountains at an altitude of $2666 \mathrm{~m}$ asl. In Tripura, the species grows at altitudes of 16-17 m asl. and a soil pH of 5.56-6.16 (Majumdar et al. 2011). On the Kas Plateau, this species grows at an altitude of $1310 \mathrm{~m}$ asl. (Pawar et al. 2012). In Northeast India, D. burmanni is often found at an altitude of $91.3 \mathrm{~m}$ asl. (Yanthan et al. 2017). In Trengganu (Malay Peninsula), this species grows on a gravel road on the sandy BRIS crossing Melaleuca cajuputi swamp (Jamilah et al. 2009). Therefore, D. burmanni can grow from a beach to a mountainous habitat of $2666 \mathrm{~m}$ asl.

In the Wolobobo Botanic Gardens, D. burmanni was only found in an open area on a footpath and the soil $\mathrm{pH}$ was 6.66 (Table 2). In Jalpaiguri, D. burmanni grows on wasteland, playgrounds, and banks of small water bodies, and soil of $\mathrm{pH}$ 5.5-6.5 (Chakraborty and Bhattacharya 2013). In Northeast India, this species usually grows on acidic and sandy soils (Yanthan et al. 2017). In Tripura, it grows at a soil pH of 5.56-6.16 (Majumdar et al. 2011). Soil $\mathrm{pH}$ can help us determine the nutrient ions absorbed by plants. In general, nutrients will be easily absorbed by plants at $\mathrm{pH}$ 6.5-7.5 (neutral), because at that $\mathrm{pH}$ most nutrients will be easily dissolved in water. So, species 
richness is high in such neutral soils, declining in both acidic and alkaline soils (Grime 1973). Soil pH is an environmental parameter related to nutrient and toxic element availability (Pausas and Austin 2001).

Wolobobo Botanic Gardens has two types of soil orders, namely inceptisol and mollisol. Inceptisol soil is a young soil that has not developed yet, so most of this soil is quite fertile. Based on the old soil classification system, it is alluvial soil, andosol, regosol, glei humus, and others. Mollisols are soils that have a dark surface horizon, are relatively rich in organic matter and have high fertility. These soils are rich in basic cations $\left(\mathrm{Ca}^{2+}, \mathrm{Mg}^{2+}, \mathrm{Na}^{+}\right.$, and $\mathrm{K}^{+}$) as essential nutrients for plants. In Indonesia, mollisol is found generally in limestone hilly areas. This soil is formed under low, medium or high grass vegetation (Purnomo et al. 2019). Therefore, D. burmanni is tolerant of various soil conditions from slightly acidic $\mathrm{pH}$ (5.5-6.5) to neutral (6.6-7.5).

Based on the assessment criteria of the soil analysis results (Soil Research Institute 2005), the content categories of each soil element in the Wolobobo Botanic Gardens are as follows: the element that was classified very high is C-organic (> 5\%); high is $\mathrm{C} / \mathrm{N}$ ratio (16-25);

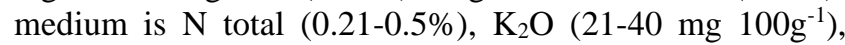
and $\mathrm{P}_{2} \mathrm{O}_{5}\left(21-40 \mathrm{mg} 100 \mathrm{~g}^{-1}\right)$; low is CEC (5-16 me $\left.100 \mathrm{~g}^{-1}\right)$; and the very low categories are $\mathrm{K}\left(<0.1 \mathrm{cmol} \mathrm{kg}^{-1}\right), \mathrm{Na}$ $\left(<0.1 \mathrm{cmol} \mathrm{kg}^{-1}\right), \mathrm{Ca}\left(<2 \mathrm{cmol} \mathrm{kg}^{-1}\right), \mathrm{Mg}\left(<0.3 \mathrm{cmol} \mathrm{kg}^{-1}\right)$, and $\mathrm{BS}(<20 \%)$ (Table 2). A high $\mathrm{C} / \mathrm{N}$ ratio means that the process of soil decomposition in the D. burmanni habitat is very slow. $\mathrm{C} / \mathrm{N}$ ratio ratios lower than 10 imply that low levels of organic matter are being merged into the soil system (Saikh et al. 1998; Yimer et al. 2007). The level of $\mathrm{K}$ availability is strongly influenced by $\mathrm{pH}$ and base saturation. In soil conditions with a neutral $\mathrm{pH}$ concentration and very low base saturation, the $\mathrm{K}$ concentration is not bound by $\mathrm{Ca}$.

Cations can be exchanged at a very low rate, because the habitat of $D$. burmanni has a rough soil texture with a single-grained structure, so the soil is porous, the air spaces are large, and the infiltration speed is high. This condition causes the mobile nutrients to be easily lost in the soil. How cations can be exchanged is very closely related to $\mathrm{BS}$, because BS shows the level of leaching bases in the soil. Based on the results of soil analysis at other locations within the Wolobobo Botanic Gardens, the overall soil sample is categorized as a rough fraction. There is even a sample of soil that has a fraction with sand concentration $>$ 90\% and clay concentration $<5 \%$ (Purnomo et al. 2019).

Many insectivorous species live in freshwater bogs and rock outcroppings where nitrogen is not present in the correct form, because the $\mathrm{pH}$ of the water is extremely acidic. On the Kas Plateau (India), D. burmanni is found in low nutrient, lateritic soil, deficient in nitrogen, and phosphorus (Pawar et al. 2012). Thus, D. burmanni is very adaptable to various soil conditions ranging from marginal land to productive land in the tropics.

\section{Plant species in the habitat of Drosera burmanni}

Drosera burmanni is an acaulescent, insectivorous herb, to $15 \mathrm{~cm}$ tall. Leaves radiate in a rosette, $1-2 \mathrm{~cm}$ in diameter, obovate or orbicular in shape, greenish to red, clothed with numerous gland-tipped hairs, mucilaginous when fresh. Flowers white or pinkish-white, few-flowered (3-10), in a terminal $5-15 \mathrm{~cm}$ long scape, arising from the cluster of leaves; sepals glandular; petals reddish, glandular. Fruit capsules, subglobose (Figure 2.A) (Marchant and George 1982; Pawar et al. 2012). The species is not easily seen in the Botanic Gardens at Wolobobo, because it is small and only found in the bushsavanna vegetation (Figure 2.B). The bush-savanna vegetation is a type of vegetation that is dominated by shrubs and herbs. In the process of succession, this type of vegetation is the initial vegetation. Over the next several decades, this type of vegetation can develop into a mixed forest containing native and introduced species.

Drosera burmanni is a carnivorous plant species and grows with other plant species. In the habitat of $D$. burmanni in the Wolobobo Botanic Gardens, its density is 8.5 individuals per $\mathrm{m}^{2}$ and at least 20 plant species are found included in 19 genera and 9 families. In terms of density, the population of the species in the Wolobobo Botanic Gardens was higher than the density in Jalpaiguri with density of 6.57 individuals per $\mathrm{m}^{2}$ (Chakraborty and Bhattacharya 2013). The species found in the habitat of $D$. burmanni in the Tripura District (India) are 30 species, which are included in 25 genera and 18 families (Majumdar et al. 2011); and the Jalpaiguri District as many as 22 species, which are included in 22 genera and 16 families (Chakraborty and Bhattacharya 2013). From these three research sites, 64 species were found, which are included in 56 genera and 29 families, growing in the habitat of D. burmanni (Table 3 and Figure 3).

Table 2. Results of soil analysis in the Drosera burmanni habitat

\begin{tabular}{|c|c|c|c|c|c|c|c|c|c|c|c|c|}
\hline \multirow{2}{*}{$\begin{array}{c}\begin{array}{c}\text { Soil } \\
\text { samples }\end{array} \\
\end{array}$} & \multirow{2}{*}{ pH } & \multirow{2}{*}{$\begin{array}{c}\text { C-org } \\
(\%)\end{array}$} & \multirow{2}{*}{$\begin{array}{c}\text { N-total } \\
(\%)\end{array}$} & \multirow{2}{*}{$\begin{array}{l}\mathrm{C} / \mathrm{N} \\
\text { ratio }\end{array}$} & \multirow{2}{*}{$\begin{array}{c}\mathrm{P}_{2} \mathrm{O}_{5}(\mathrm{mg} \\
\left.100 \mathrm{~g}^{-1}\right)\end{array}$} & \multirow{2}{*}{$\begin{array}{c}\mathrm{K}_{2} \mathrm{O}(\mathrm{mg} \\
\left.100 \mathrm{~g}^{-1}\right)\end{array}$} & \multicolumn{4}{|c|}{ Exchangeable cations (cmol / kg) } & \multirow{2}{*}{$\begin{array}{c}\text { CEC } \\
(\mathrm{me} / 100 \mathrm{~g})\end{array}$} & \multirow{2}{*}{ BS (\%) } \\
\hline & & & & & & & $\mathbf{K}$ & $\mathbf{N a}$ & $\mathbf{C a}$ & Mg & & \\
\hline A & & 5.33 & 0.33 & 16 & 30.26 & 30.26 & 0.06 & 0 & 1.21 & 0.23 & 10.08 & \\
\hline B & 6.64 & 5.14 & 0.29 & 18 & 23.76 & 23.76 & 0.07 & 0.01 & 1.37 & 0.23 & 9.97 & 16.85 \\
\hline
\end{tabular}

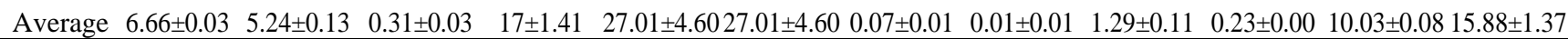
Note: CEC: Cation Exchange Capacity, BS: Base Saturation 


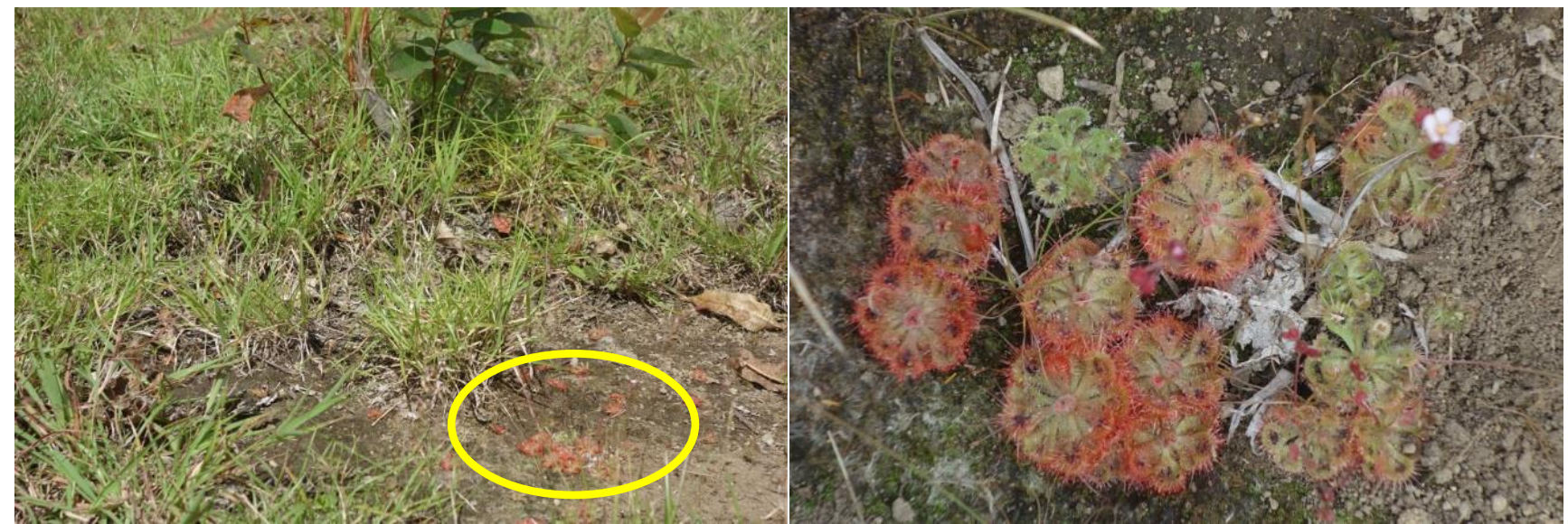

Figure 2. Drosera burmanni in the Wolobobo Botanic Gardens, Ngada District, East Nusa Tenggara, Indonesia

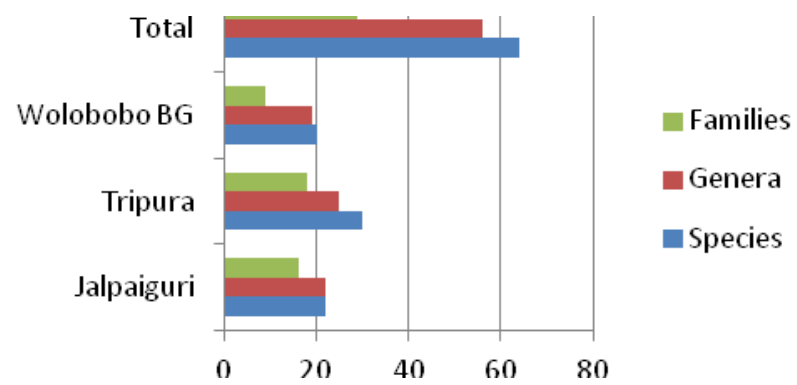

Figure 3. The plant species grow in the habitat of Drosera burmanni in three research sites

The plant species that grow in the habitat of $D$. burmanni in the Wolobobo Botanic Gardens is dominated by species of Asteraceae with seven species, followed by Poaceae with four species, Cyperaceae and Leguminosae with two species respectively, and Apiaceae, Gleicheniaceae Melastomataceae, Myrtaceae and Polygalaceae with one species, respectively. These species have broad distribution areas, except for Eucalyptus urophylla from the Lesser Sunda Islands (www.theplantlist.org 2020).

Based on these three research sites, 64 plant species grow together with Drosera burmanni. only Centella asiatica was found in all research sites. This species is distributed in pantropical areas from South-East Asia and extending into some subtropical regions. Physiologically, C. asiatica has a long creeping stolon, up to $2.5 \mathrm{~m}$ long, rooting at the nodes, growing flowers, and fruits yearround. This species can easily regenerate via runners which root at the nodes and seed. Ecologically, Asiatic pennywort occurs in sunny or slightly shaded, damp localities on fertile soils, in open grassland, and from sea-level up to $2500 \mathrm{~m}$ asl. Physiological and ecological characters support the ability of this species to adapt to various environmental conditions. Although considered a weed, it has been used traditionally as a medicinal plant, for skincare, as a vegetable, and in beverages in South-East Asia, India, and China (Hargono et al. 1999).

\section{Distribution patterns and plant associations Distribution pattern}

Based on the data analysis, the Morisita Index of Dispersion (Id) is 2.675 ( $\mathrm{Id}>1$ ), the Uniform Index (Mu) is 0.99, the Clumped Index (Mc) is 1.02, and the Standardized Morisita Index (Ip) is 0.524 (Ip>0). These index values indicate that the distribution of $D$. burmanni has a clustering pattern. The results support Jamilah et al. (2009), where D. burmanni in Trengganu (Malay Peninsula) also has a clustered distribution pattern.

The distribution pattern of D. burmanni, which is clustered, is influenced by its habitat and how it reproduces. The species was only found in one location in the Wolobobo Botanic Gardens, which indicates that it requires certain habitat conditions to grow, reproduce and survive. Regeneration of $D$. burmanni occurs sexually with seeds and asexually or vegetatively with gemmae (fragmentation) (Jamilah et al. 2009). If environmental conditions support germination, the seeds will grow into new individuals that are not far from their parents. Regeneration with gemmae also produces new individuals that are born not far from the parent plant. This could explain the reason why $D$. burmanni plants grow in a cluster (group).

\section{Plant association}

Based on the chi-square test, it is known that of the 20 species found in the observation plot in the Wolobobo Botanic Gardens (Table 3), there are only three species associated with D. burmanni: Erigeron sumatrensis, Imperata cylindrica, and Spinifex littoreus (Table 4). The association level with the Jaccard index is 0 to 1 , if the Jaccard index is close to 1 , the association level is high (Ludwig and Reynolds 1988). The association level of $D$. burmanni and E. sumatrensis has the highest Jaccard index, 0.857 , followed by D. burmanni and $S$. littoreus at 0.828 , and D. burmanni and I. cylindrica at 0.458 . 
Table 3. The species grows in the habitat of Drosera burmanni in the Wolobobo Botanic Gardens (Indonesia), Tripura District (India), and Jalpaiguri District (India)

\begin{tabular}{|c|c|c|c|c|}
\hline Species & Family & $\begin{array}{l}\text { Wolobobo BG } \\
\text { Ngada District }\end{array}$ & $\begin{array}{c}\text { Tripura District, } \\
\text { India* }\end{array}$ & $\begin{array}{c}\text { Jalpaiguri District, } \\
\text { India** }\end{array}$ \\
\hline Nelsonia canescens (Lam.) Spreng. & Acanthaceae & - & + & - \\
\hline Centella asiatica (L.) Urb. & Apiaceae & + & + & + \\
\hline Holarrhena pubescens Wall. ex G.Don & Apocynaceae & - & + & - \\
\hline Hydrocotyle sibthorpioides Lam. & Araliaceae & - & + & - \\
\hline Rorippa indica (L.) Hiern & Brassicaceae & - & - & + \\
\hline Stellaria media (L.) Vill. & Caryophyllaceae & - & - & + \\
\hline Ageratum conyzoides $\mathrm{L}$. & Asteraceae & + & - & - \\
\hline Bidens pilosa $\mathrm{L}$. & Asteraceae & + & - & - \\
\hline Chromolaena odorata (L.) RMKing \& H.Rob. & Asteraceae & + & + & - \\
\hline Crassocephalum crepidioides (Benth.) S.Moore & Asteraceae & + & - & - \\
\hline Cyanthillium cinereum (L.) H.Rob. & Asteraceae & - & - & + \\
\hline Eclipta prostrata $(\mathrm{L}.) \mathrm{L}$. & Asteraceae & - & - & + \\
\hline Emilia sonchifolia (L.) DC. & Asteraceae & + & - & - \\
\hline Erigeron sumatrensis Retz. & Asteraceae & + & - & - \\
\hline Sonchus arvensis $\mathrm{L}$. & Asteraceae & + & - & - \\
\hline Cyperus ciliata Vahl & Cyperaceae & - & + & - \\
\hline Cyperus papyrus $\mathrm{L}$. & Cyperaceae & + & - & - \\
\hline Cyperus rotundus $\mathrm{L}$. & Cyperaceae & + & - & - \\
\hline Cyperus sp. & Cyperaceae & - & - & + \\
\hline Fimbristylis aestivalis Vahl & Cyperaceae & - & + & - \\
\hline Fimbristylis dichotoma (L.) Vahl & Cyperaceae & - & + & - \\
\hline Fimbristylis quinquangularis (Vahl) Kunth & Cyperaceae & - & + & - \\
\hline Fuirena ciliaris (L.) Roxb. & Cyperaceae & - & + & - \\
\hline Pycreus pumilus (L.) Nees & Cyperaceae & - & + & - \\
\hline Eriocaulon cinereum $\mathrm{R} . \mathrm{Br}$. & Eriocaulaceae & - & + & - \\
\hline Euphorbia hirta L. & Euphorbiaceae & - & - & + \\
\hline Dicranopteris linearis (Burm.f.) Underw. & Gleicheniaceae & + & - & - \\
\hline Leucas zeylanica (L.) W.T.Aiton & Lamiaceae & - & - & + \\
\hline Vitex Peduncularis Wall. ex Schauer & Lamiaceae & - & + & - \\
\hline Acacia auriculiformis Benth. & Fabaceae & - & + & - \\
\hline Sesbania sesban (L.) Merr. & Fabaceae & + & - & - \\
\hline Alysicarpus vaginalis (L.) DC. & Fabaceae & - & + & - \\
\hline Grona triflora (L.) H.Ohashi \& K.Ohashi & Fabaceae & + & - & + \\
\hline Ammannia baccifera $\mathrm{L}$. & Lythraceae & - & + & - \\
\hline Microcos paniculata $\mathrm{L}$. & Malvaceae & - & + & - \\
\hline Melastoma malabathricum $\mathrm{L}$. & Melastomataceae & + & + & - \\
\hline Eucalyptus urophylla S.T.Blake & Myrtaceae & + & - & - \\
\hline Mazus pumilus (Burm.f.) Steenis & Phrymaceae & - & - & + \\
\hline Glochidion Ellipticum Wight & Phyllanthaceae & - & + & - \\
\hline Limnophila chinensis (Osbeck) Merr. & Plantaginaceae & - & + & - \\
\hline Lindenbergia indica Vatke & Plantaginaceae & - & - & + \\
\hline Mecardonia procumbens (Mill.) Small & Plantaginaceae & - & - & + \\
\hline Scoparia dulcis L. & Plantaginaceae & - & - & + \\
\hline Axonopus compressus (Sw.) P.Beauv. & Poaceae & + & - & - \\
\hline Brachiaria ciliata (L.) Stapf & Poaceae & - & - & + \\
\hline Chrysopogon aciculatus (Retz.) Trin. & Poaceae & - & + & + \\
\hline Cynodon dactylon (L.) Pers. & Poaceae & - & - & + \\
\hline Dichanthium caricosum (L.) A.Camus & Poaceae & - & + & - \\
\hline Eleusine indica (L.) Gaertn. & Poaceae & + & - & - \\
\hline Imperata cylindrica (L.) P.Beauv. & Poaceae & + & - & + \\
\hline Panicum brevifolium $\mathrm{L}$. & Poaceae & - & + & - \\
\hline Panicum sumatrense Roth & Poaceae & - & + & - \\
\hline Spinifex littoreus (Burm.f.) Merr. & Poaceae & + & - & - \\
\hline Polygala paniculata $\mathrm{L}$ & Polygalaceae & + & - & - \\
\hline Jasminum nervosum Lour. & Oleaceae & - & + & - \\
\hline Ludwigia perennis $\mathrm{L}$. & Onagraceae & - & - & + \\
\hline Oxalis corniculata $\mathrm{L}$. & Oxalidaceae & - & - & + \\
\hline Utricularia gibba $\mathrm{L}$. & Lentibulariaceae & - & + & - \\
\hline Lindernia antipoda (L.) Alston & Linderniaceae & - & + & - \\
\hline Lindernia ciliata (Colsm.) Pennell & Linderniaceae & - & + & - \\
\hline Lindernia crustacea (L.) F.Muell. & Linderniaceae & - & - & + \\
\hline Oldenlandia corymbosa $\mathrm{L}$. & Rubiaceae & - & + & + \\
\hline Selaginella sp. & Selaginellaceae & - & - & + \\
\hline Rotala indica (Willd.) Koehne & Lythraceae & - & + & - \\
\hline Total & $\begin{array}{c}64 \text { sp, } 56 \text { gen, } \\
29 \text { fam }\end{array}$ & $\begin{array}{c}20 \text { sp, } 19 \text { gen, } 9 \\
\text { fam }\end{array}$ & $\begin{array}{c}30 \text { sp, } 25 \text { gen, } 18 \\
\text { fam }\end{array}$ & $22 \mathrm{sp}, 22$ gen, 16 fam \\
\hline
\end{tabular}

Note: *: Majumdar et al. (2011), **: Chakraborty and Bhattacharya (2013), +: present, -: absent 
Table 4. Chi-square test level and type of association between Drosera burmanni and other plant species

\begin{tabular}{lcccc}
\hline Species & $\mathbf{X}^{\mathbf{2} \text { count }}$ & $\begin{array}{c}\text { Chi-squared test } \\
\text { results }\end{array}$ & Jaccard Index & Association type \\
\hline D. burmanni vs Erigeron sumatrensis & 8.571 & An association & 0.857 & Positive \\
D. burmanni vs Imperata cylindrica & 4.342 & An association & 0.458 & Positive \\
D. burmanni vs Spinifex littoreus & 4.138 & An association & 0.828 & Positive \\
\hline
\end{tabular}

Note: Significant association is 0.05

The type of association between D. burmanni and Erigeron sumatrensis, Spinifex littoreus, and Imperata cylindrica is positive, which means that there is a similarity in their habitat requirements, and that they tolerate living together and sharing the available resources, and that they have a broad overlapping niche ( $\mathrm{Su}$ et al. 2015). The observations in the field show that most individuals of $D$. burmanni share spaces with E. sumatrensis and S. littoreus, tolerating each other by sharing the available resources.

Most individuals of $D$. burmanni grow in open areas without any shade from other plants. Some individuals do grow under the shade of other plant species. So, $D$. burmanni can grow in the shade or open areas. The results of these observations differ from Chakraborty and Bhattacharya (2013) where D. burmanni is only found in an open area and not found under the shade of other plant species.

\section{Conservation efforts}

Drosera burmanni was only found in one location in the Wolobobo Botanic Gardens. It is a small population in a very restricted area making this species very vulnerable in the region. Based on the previous studies, destruction of natural habitats and eutrophication are the main causes of Drosera population reduction. In fact, some species of Drosera in Europe are scarce (Lange 1998; Banasiuk et al. 2012). The Switzerland government has established a rule that Drosera collections from natural habitats can only be used for research purposes and require special permission from the government. In France, native Drosera species, such as $D$. anglica, $D$. intermedia, and $D$. rotundifolia have been designated as protected plant species. The collection, use, transport or trade of these species require special permission from the relevant French ministries (Baranyai and Joosten 2016).

Several states in the United States have established $D$. rotundifolia as a protected plant species, because it is included in the list of threatened or endangered species (USDA 2015). On the other hand, the species of Drosera in Asia, Africa, and Latin America have not received much attention from their local governments, due to the limited research and use of Drosera. Information concerning Drosera's scarcity status from these areas has never been reported.

The Wolobobo Botanic Gardens is managed by the Ngada District Government. The compilation of the masterplan completed in 2019 will be followed up with the infrastructure construction starting in 2020. As an ex situ conservation center for the Lesser Sunda Islands mountain vegetation, the management authority of the Wolobobo Botanic Gardens needs to establish the D. burmanni habitat as an in situ conservation area at the location where the species and other native plants grow. Thus, preventing activities that change the landscape due to infrastructure development at the Wolobobo Botanic Gardens from being carried out in the natural habitat of D. burmanni. On the other hand, efforts to propagate and do research on the use of this species need to be done in parallel. According to Yanthan et al. (2017), in vitro propagation of D. burmanni with shoots showed significant results in the propagation and conservation of this species.

In the Bogor Botanic Gardens, in situ conservation areas have been established for the conservation of Dydimoplexis pallens, "invisible orchids", which only appear at certain times (Mursidawati and Handini 2009), and in the Cibodas Botanic Gardens for the conservation of native plants of Gunung-Gede Pangrango (Mutaqien and Zuhri 2011). Protection of the area is a better way to conserve and safeguard the species from tourists. So both in situ and ex situ conservation is needed in the Wolobobo Botanic Gardens, mainly to conserve indigenous and local species.

In conclusion, In the Wolobobo Botanic Gardens, $D$. burmanni flourishes with an average annual rainfall of $1835 \mathrm{~mm}$; a temperature of $12.50-26.2^{\circ} \mathrm{C} ; 48-99 \%$ humidity; at an altitude of 1489-1491 m asl.; a soil pH of 6.66, which contains very high $\mathrm{C}$-organic; a high $\mathrm{C} / \mathrm{N}$ ratio; moderate $\mathrm{N}$ total, $\mathrm{K}_{2} \mathrm{O}, \mathrm{P}_{2} \mathrm{O}_{5}$; low $\mathrm{CEC}$ (Cation Exchange Capacity), and very low $\mathrm{K}, \mathrm{Na}, \mathrm{Ca}, \mathrm{Mg}$, and BS (Base Saturation). D. burmanni is associated with 20 species, which belong to 19 genera and 9 families. The species has a clustering pattern and a positive association with Erigeron sumatrensis, Spinifex littoreus, and Imperata cylindrica. To conserve D. burmanni in the Wolobobo Botanic Gardens, it is necessary to designate its natural habitat as an in situ conservation area. Protection of the area is a better way to conserve and safeguard the species from tourists.

\section{ACKNOWLEDGEMENTS}

Thank you to Paulus Soliwoa (Major of Ngada District) and Hilarius Sutanto (Head Planning, Research and Development Agency, Ngada District) for facilitating our field research. Many thanks are also addressed to the team of the Wolobobo Botanic Gardens Masterplan for supporting this research activity. 


\section{REFERENCES}

APG (Angiosperm Phylogeny Group) IV. 2016. An update of the Angiosperm Phylogeny Group classification for the orders and families of flowering plants: APG IV. Bot J Linn Soc 181: 1-20.

Banasiuk R, Kawiak A, Królicka, A. 2012. In vitro cultures of carnivorous plants from the Drosera and Dionaea genus for the production of biologically active secondary metabolites. BioTechnologia 93 (2): 87-96.

Baranyai B, Joosten H. 2016. Biology, ecology, use, conservation and cultivation of round-leaved sundew (Drosera rotundifolia L.): a review. Mires Peat 18: 1-28. DOI: 10.19189/MaP.2015.OMB.212

Brittnacher J. 2020. Growing Drosera burmannii and D. sessilifolia. International Carnivorous Plant Society. https://www.carnivorousplants.org/grow/guides/Dburmannii_Dsessili folia

Hema B, Bhupendra S, Mohamed Saleem TS, Gauthaman K. 2009. Anticonvulsant effect of Drosera burmanni Vahl. Intl J Appl Res Nat Prod 2 (3): 1-4.

Chakraborty S, Bhattacharya M. 2013. Associated vegetation of sundew (Drosera burmanni Vahl.) in plains of Eastern Himalayan region of West Bengal. Environ Ecol 31 (2B): 840-843.

Dogan Y. 2001. Study on the autecology of Reseda lutea L. (Resedaceae) distributed in Western Anatolia. Turk J Bot 25: 137-148.

Ellison AM, Gotelli NJ. 2009. Energetics and the evolution of carnivorous plants - Darwin's 'most wonderful plants in the world'. J Exp Bot 60 (1): $19-42$.

Fleischmann A, Cross AT, Gibson R, Gonella PM, Dixon KW. 2018. Systematics and evolution of Droseraceae. In: Ellison AM, Adamec L. (eds) Carnivorous Plants: Physiology, Ecology, and Evolution. Oxford University Press. DOI: 10.1093/oso/ 9780198779841.003.0004

Ghate NB, Chaudhuri D, Das A, Panja S, Mandal N. 2015. An antioxidant extract of the insectivorous plant Drosera burmanni Vahl. alleviates iron-induced oxidative stress and hepatic injury in mice. PLoS ONE 10 (5): e0128221. DOI: 10.1371/journal.pone.0128221

Godeanu S, Doniță N. 2016. How are approached species and population in biology and ecology. Acad Rom Scien Ann - Ser Biol Sci 5 (2): $57-$ 66.

Gonin P, Larrieu L, Coello J, Marty M, Lestrade M, Becquey J, Claessens H. 2013. Autecology of broadleaved species. Institut pour le Développement Forestier, Paris.

Grime JP. 1973. Competitive exclusion in herbaceous vegetation. Nat UK 242: 344-347.

Gunawan, Chikmawati, T, Sobir, Sulistijorini. 2018. Distribution and Autecology of Belimbing Merah (Baccaurea angulata Merr.) in Kalimantan. IOP Conference Series: Earth Environ Sci 197: 012022. DOI: $10.1088 / 1755-1315 / 197 / 1 / 012022$.

Hargono D, Lastari P, Astuti Y, van den Bergh MH. 1999. Centella asiatica (L.) Urb. in. de Padua LS, Bunyapraphatsara N, Lemmens RHMJ. (eds) Plant Resources of South-East Asia No. 12 (1) Medicinal and Poisonous Plants 1. Backhuys Publishers, Leiden, The Netherlands.

http://www.climate-data.org. 2020. Bajawa climate. https://en.climatedata.org/asia/indonesia/east-nusa-tenggara/bajawa-4316.

http://www.plantsoftheworldonline.org/taxon/urn:lsid:ipni.org:names:300 01036-2

Jaccard P. 1901. Étude comparative de la distribution florale dans une portion des Alpes et du Jura. Bull Soc Vaud Sci Nat 37: 547-549.

Jamilah MS, Nur-Atiqah MH, Nurul-Effadah S, Nur-Khairulhusna I 2009. Pigmy Drosera (Droseraceae) from heath forest on BRIS soil of Setiu, Terengganu. Fol Mal 10 (1): 33-40

Kalkman C. 1955. A Plant-geographical analysis of the Lesser Sunda Islands. Acta Bot Neerl 4 (2): 200-225.

Kottek M, Grieser J, Beck C, Rudolf B, Rubel F. 2006. World map of the Köppen-Geiger climate classification updated. Meteorol Z 15 (3): 259-263. DOI: 10.1127/0941-2948/2006/0130

Krebs CJ. 1989. Ecological Methodology. Harper \& Row Publisher, New York.

Ludwig JA, Reynolds JF. 1988. Statistical Ecology: A Primer on Methods and Computing. John Wiley and Sons, Singapore.

Lange D. 1998. Europe's Medicinal and Aromatic Plants: Their Use, Trade and Conservation. A Traffic Network report, Traffic International, Cambridge

Lele YA. 2015. Creating roadmap of conservation management for a UNESCO world natural heritage in India: A case study of Kaas plateau, India. 4th International Conference on Biodiversity. OMICS International Cenferenceseries.com. Las Vegas, 15-17 June 2015. USA.

Madhavan V, Kumar BHP, Murali A, Yoganarasimhan SN. 2009. Antifertility activity of Drosera burmanni. Pharm Biol 47 (2): 128131. DOI: $10.1080 / 13880200802437149$

Majumdar K, Datta BK, Shankar U. 2011. Community structure and population status of Drosera burmanni Vahl. with new distributional record in Tripura, India. J Ecol Nat Environ 3 (13): 410-414.

Mansur M. 2012. Diversity of insectivorous plants and its photosynthetic rate in Natuna Island. Berita Biologi 11 (1): 33-42. [Indonesian]

Marchant NG, George AS. 1982. Drosera. In: George AS (ed.) Flora of Australia 8: 9-64. Australian Government Publishing Service, Canberra.

Mitra S, Mukherjee SK. 2010. Etnomedicinal usages of some wild plants of North Bengal plain for gastro-intestinal problem. Ind J Tradit Knowl 9: 705-712.

Mursidawati S, Handini E. 2009. Conservation biology of mycoheterotrophic orchid: case study of in-vitro culture of Dydimoplexis pallens (Orchidaceae). Proceeding ICBS, Faculty of Biology, Gadjah Mada University, Yogyakarta.

Mutaqien Z, Zuhri M. 2011. Establishing a long-term permanent plot in remnant forest of Cibodas Botanic Garden, West Java. Biodiversitas 12 (4): 218-224

Pausas JG, Austin MP. 2001. Patterns of plant species richness in relation to different environments: an appraisal. J Veg Sci 12: 153-166.

Pawar SM, Mohite SA, Sonawane SR. 2012. Drosera burmanni and Drosera indica - need of conservation from Kas Plateau (World's Natural Heritage Site). Int J Pharm Biol Med Sci 1 (1): 26-28.

Purnomo DW, Witono JR, Usmadi D, Lubis RF, Safarinanugraha D, Widoretno A, Putri WU, Wihermanto, Guswandi D, Suyanto, Asnidar Y, Zulfa H. 2019. Final Report of The Wolobobo Botanical Garden Masterplan. Research Center for Plant Conservation and Botanic Gardens. Indonesian Institute of Sciences, Bogor. [Indonesian]

Quek ZBR, Chui SX, Lam WN, Fung TK, Sivasothi N. 2020. Autecology of the common fishtail palm, Caryota mitis (Arecaceae), in Singapore. Bot Lett. DOI: 10.1080/23818107.2020.1717612

Raju A, Christina AJM, Mayakrishnan A. 2012. Antitumor potential of ethanol and aqueous extracts of Drosera burmanni Vahl against Dalton's ascitic lymphoma bearing mice. J Pharm Res 5 (3): 14181423

Raju A, Christina AJM. 2013. Drosera burmanni Vahl: antioxidant potential in Dalton's Ascites Lymphoma (DAL) bearing mice. J Med Plants Stud 1 (4): 152-159.

Robinson AS, Nunn R, Bourke G, McPherson SR, Fleischmann A. 2017. The genus Drosera. In: Lowrie A, Nunn R, Robinson AS, Bourke G, McPherson SR, Fleischmann A. (eds) Drosera of the World 1: Oceania. Redfern Natural History Productions, Dorset.

Saikh H, Varadachari C, Kunal G. 1998. Changes in carbon, nitrogen and phosphorus levels due to deforestation and cultivation: A case study in Simlipal National Park, India. Plant Soil 198: 137-145.

Soil Research Institute. 2004. Technical Guidelines on Analysis of Soil Chemicals, Plants, Water, and Fertilizers. Agricultural Research and Development Agency. Ministry of Agriculture. Bogor. [Indonesian]

Su SJ, Liu JF, He ZS, Zheng SQ, Hong W, Xu DW. 2015. Ecological species groups and interspesific association of dominant tree species in Daiyun Mountain National Nature Reserve. J Mt Sci 12 (3): 637 646.

USDA. 2015. Threatened and endangered species/protected plants for all scientific names-Drosera rotundifolia. http://plants.usda.gov/java/threat, accessed 04 Jan 2015.

Widyatmoko D. 2001. Autecology and Conservation Management of Rare Palm Species : The Case Study of Lipstick Palm Cyrtostachys renda Blume in Kerumutan Wildlife Sanctuary, Riau. [Dissertation]. Posgraduate Programme, Bogor Agricultural University, Bogor. [Indonesian]

Yanthan JS, Kehie M, Kumaria S, Tandon P. 2017. In vitro regeneration of Drosera burmanni Vahl.: a carnivorous plant of north-east India. Biotech 7: 124. DOI 10.1007/s13205-017-0777-7.

Yimer F, Ledin S, Abdelkadir A. 2007. Changes in soil organic carbon and total nitrogen contents in three adjacent land use types in the Bale Mountains, South-Eastern highlands of Ethiopia. For Ecol Manag 242: $337-342$

Zhuang X. 2011. Drosera burmanni. The IUCN Red List of Threatened Species 2011: e.T169038A6566220. DOI: 10.2305/IUCN.UK.20111.RLTS.T169038A6566220. 